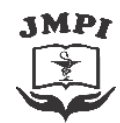

Jurnal Mandala Pharmacon Indonesia, Vol 7.No.1 Juni 2021

Avaiable online at www.jurnal-pharmaconmw.com/jmpi

p-ISSN : 2442-6032

e-ISSN : 2598-9979

\title{
Evaluasi toksisitas Madu hasil produksi lebah yang diberi pakan tambahan ekstrak air Moringa oleifera terhadap larva Artemia salina
}

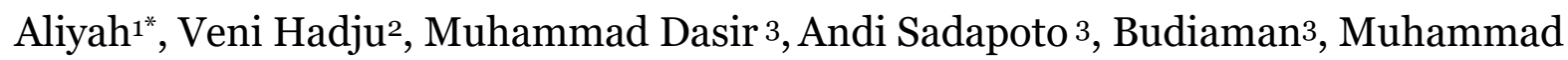 \\ Raihan ${ }^{1}$ \\ ${ }^{1}$ Fakultas Farmasi, Universitas Hasanuddin, Makassar, Indonesia \\ ${ }^{2}$ Fakultas Kesehatan Masyarakat, Universitas Hasanuddin, Makassar, Indonesia \\ 3Fakultas Kehutanan Universitas Hasanuddin, Makassar, Indonesia
}

\begin{abstract}
ABSTRAK
Madu dan Moringa oleifera merupakan salah satu bahan alam yang memiliki nilai nutrisi dan potensi sebagai bahan obat yang cukup besar. Penelitian ini bertujuan untuk mengevaluasi toksisitas madu hasil ternak lebah yang diberi pakan sirup sukrosa dengan suplementasi M. oleifera menggunakan Artemia salina sebagai hewan model. Komponen madu kelor (MK) dan M. oleifera mula-mula dianalisis dengan menggunakan sistem HPTLC dengan fase gerak terdiri dari n-heksana dan etil asetat dengan perbandingan 2:1. Toksisitas MK kemudian diuji menggunakan $A$. salina sebagai model organisme dengan konsentrasi antara 10 hingga $2000 \mu \mathrm{g}$ / ml dalam media air laut buatan. Tingkat kematian dilaporkan dalam persentase $A$. salina jumlah larva yang mati terhadap total larva yang diuji. Nilai $\mathrm{LC}_{50}$ dihitung
\end{abstract}

dengan menggunakan analisis probit. Hasil analisis pada penelitian ini menunjukkan bahwa beberapa komponen $M$. oleifera dapat dideteksi pada MK berdasarkan nilai Rf yang diperoleh dalam analisis HPTLC. Selanjutnya, berdasarkan nilai $\mathrm{LC}_{50}$ dalam penelitian ini, MK dianggap sebagai bahan dengan toksisitas yang rendah. Namun, penelusuran lebih lanjut pada komponen fitokimia yang bertanggung jawab pada toksisitas ini perlu dilakukan untuk melihat korelasinya dengan toksisitas MK.

Kata kunci : Madu Kelor, Toksisitas, Artemia salina, Moringa oleifera

\begin{abstract}
Honey and Moringa oleifera are both natural products that have high nutritional and medicinal values. This study aims to evaluate the toxicity of honey obtained from bees that were fed with sucrose syrup supplemented with $M$. oleifera juice using Artemia salina as the animal model. The component of Moringa Honey (MH) and $M$. oleifera was initially examined using HPTLC systems with mobile phase consisted of n-

were reported in percentages of dead A. salina larvae and the $\mathrm{LC}_{5} \mathrm{O}$ value was calculated using probit analysis. Our finding suggested that constituents of $M$. oleifera might be present in $\mathrm{MH}$ based on the Rf values obtained in the HPTLC analysis. Furthermore, the $\mathrm{LC}_{50} \mathrm{O}$ value of $\mathrm{MH}$ in this assay is considered as low toxic and further investigation on the corresponding phytochemical is required to correlate the toxicity of $\mathrm{MH}$.
\end{abstract} hexane and ethyl acetate at a ratio of 2:1. The toxicity of MH was examined using Artemia salina as the model organism starting at the concentration of o to 2000 $\mu \mathrm{g} / \mathrm{ml}$ of $\mathrm{MH}$ in a saltwater medium. The mortality rates
Keywords: Moringa Honey, Toxicity, Artemia salina, Moringa oleifera
Penulis Korespondensi :

Aliyah

Fakultas Farmasi, Universitas Hasanuddin,

E-mail : aliyahputranto@yahoo.co.id 


\section{PENDAHULUAN}

Madu adalah salah satu produk lebah yang telah digunakan selama berabadabad karena nilai gizi dan potensinya sebagai obat bahan alam. Berbagai penelitian telah melaporkan bahwa madu dapat menunjukkan aktivitas farmakologis potensial terutama sebagai antioksidan (Biluca et al., 2020; Erejuwa et al., 2012; Estevinho et al., 2008), antikanker (Erejuwa et al., 2014)dan agen antimikroba (Israili, 2014; Kwakman \& Zaat, 2012). Meskipun secara umum komposisi utama madu sebagian besar adalah senyawa gula seperti glukosa dan fruktosa tetapi beberapa metabolit sekunder tanaman seperti fenolat dan flavonoid juga dapat ditemukan. Senyawa seperti asam caffeic, asam caffeic phenyl ester, pinocembrin, chrysin, dan galangin adalah beberapa metabolit yang paling sering dilaporkan (Oroian \& Ropciuc, 2017). Senyawa ini dianggap sebagai zat dalam madu yang bertanggung jawab atas aktivitasnya. Beberapa penelitian menunjukkan bahwa komponen fitokimia yang terdapat dalam madu sangat dipengaruhi oleh spesies tumbuhan di sekitarnya. Sebuah studi baru-baru ini juga menunjukkan bahwa DNA bunga di sekitarnya dapat dilacak dalam madu yang menunjukkan bahwa komponen tanaman dapat digabungkan ke dalam madu yang dikumpulkan (Olivieri et al., 2012; Wirta et al., 2021). Lebah madu juga telah dilaporkan sebelumnya dapat membawa senyawa fitokimia tertentu ke dalam produk lebah termasuk madu (Rowland et al., 1995).

Sebelumnya telah dilaporkan bahwa kombinasi madu dan $M$. oleifera bermanfaat untuk mengurangi risiko stres oksidatif dan menghambat paparan radikal bebas pada wanita hamil dan ibu dengan bayi baru lahir (Hadju et al., 2020). Tanaman M. oleifera sendiri dianggap sebagai sumber makanan bergizi di beberapa negara di Asia dan Afrika (Shindano \& Kasase, 2009). Daun, khususnya, telah dilaporkan mengandung nilai gizi tinggi seperti mineral (kalsium, magnesium, tembaga, besi, seng dan selenium) (Moyo et al., 2011), dan antioksidan seperti vitamin B, karotenoid, serta asam amino esensial yaitu lisin, leusin, asam glutamat dan asam aspartat (Foidl et al., 2001; Gopalakrishnan et al., 2016). Berdasarkan nilai gizi $M$. oleifera dan madu serta potensinya bila digabungkan, maka pada penelitian ini, dilakukan uji toksisitas Madu Kelor (MK) yang diproduksi dengan menambahkan pakan lebah madu dengan jus M. oleifera.

Meskipun $M$. oleifera dianggap sebagai sumber makanan di beberapa negara, masih ada beberapa penelitian yang melaporkan bukti toksisitas dalam $M$. oleifera komponendan dengan demikian lebih lanjut merekomendasikan batas konsumsinya (Obi, 2018; Rajeh et al., 2012). Berdasarkan hal tersebut, Artemia salina sebagai salah satu hewan 
model yang paling sering digunakan dapat digunakan sebagai model pengujian dalam uji toksisitas MK. Telah dilaporkan bahwa toksisitas ekstrak dan produk alami sebanding dengan pengujian pada hewan pengerat seperti pada mencit dan mencit (Parra et al., 2001; Rajeh et al., 2012). Oleh karena itu, dalam penelitian ini kami bertujuan untuk mengevaluasi toksisitas madu yang diperoleh dari lebah yang diberi makan M. oleifera jusmenggunakan A. salina sebagai hewan model.

\section{METODE PENELITIAN}

\section{A.Sumber madu}

Madu yang digunakan dalam penelitian ini diperoleh dari satu koloni Apis mellifera yang dikembangbiakkan secara tertutup dan tidak memiliki akses pada sumber flora secara bebas. Madu yang diperoleh kemudian disimpan dalam wadah tertutup dan dicegah makan dari bunga lain di sekitarnya. Lebah diberi sirup sukrosa (terdiri dari $85 \% \mathrm{~b} / \mathrm{v}$ sukrosa) yang dikombinasikan dengan $M$. oleifera jus daundengan perbandingan masing-masing 80:20. $M$. oleifera jus disiapkan dengan menggiling 500 g daun segar $M$. oleifera dengan 20 $\mathrm{ml}$ air deionisasi. Pemberian pakan dilakukan setiap hari selama 14 hari secara ad libitum. Pada hari ke 15, madu dikumpulkan dan disimpan dalam freezer sebelum diuji terhadap A. salina.

\section{B.Persiapan larva $A$. salina}

Awalnya, air laut buatan disiapkan dengan melarutkan $38 \mathrm{~g} \mathrm{NaCl}$ dalam $1 \mathrm{~L}$ air steril deionisasi (disesuaikan dengan $\mathrm{pH}$ 8,o dengan $\mathrm{NaOH} 1 \mathrm{~N}$ ). Larutan kemudian disaring, dan dipindahkan ke dalam bejana kaca setelah disterilisasi menggunakan autoklaf. Medium tersebut kemudian didinginkan hingga suhu kamar dan digunakan sebagai media untuk menetaskan $A$. salina telur. Prosedur penetasan dilakukan dengan mendispersikan $25 \mathrm{mg}$ telur ke dalam $500 \mathrm{ml}$ air asin. Telur-telur tersebut kemudian dibiarkan didispersikan dengan bantuan bubble aerator selama 24 jam dalam ruangan gelap kemudian dipindahkan ke dalam kompartemen yang dilengkapi dengan penerangan yang tersedia selama 12 jam, sehingga proses penetasan terhitung selama 36 jam.

\section{Pembuatan konsentrasi MK}

Sebanyak $125 \mathrm{mg}$ MK diencerkan dalam $25 \mathrm{ml}$ air laut yang telah disiapkan sebelumnya sehingga diperoleh konsentrasi larutan stok $5 \mathrm{mg} / \mathrm{ml}$. Kemudian, larutan ini dipindahkan ke dalam vial $10 \mathrm{ml}$ untuk membuat rangkaian konsentrasi 100, 250, 500, 1000,1500 dan $2000 \mathrm{~g} / \mathrm{ml}$. Volume total untuk setiap konsentrasi dihitung masing-masing $5 \mathrm{ml}$, tetapi volume dibuat hanya menjadi $4 \mathrm{ml}$ untuk memberikan ruang tambahan untuk $1 \mathrm{ml}$ 
air asin ketika larva dipindahkan ke dalam vial. Kontrol dilakukan dengan menggunakan media air asin tanpa sampel MK.

\section{Uji Udang Air Garam MK}

Dalam setiap larutan yang disiapkan, 10 larva dipindahkan dan di pada suhu kamar. Setelah 24 jam, larva yang bertahan hidup dihitung dan persentase kematian dihitung dengan membandingkan rata-rata jumlah kelangsungan hidup dengan total larva. Semua perlakuan dilakukan dalam tiga replikasi. Nilai LC50 kemudian dihitung menggunakan analisis probit. Selain itu, pemeriksaan morfologi larva yang masih hidup dan yang mati dilakukan dengan menggunakan mikroskop standar. Kategori toksisitas kemudian ditunjukkan dengan menggunakan interpretasi dari kriteria Clarkson (2004) seperti yang ditunjukkan pada Tabel 1 di bawah ini.

Tabel 1. Kriteria toksisitas berdasarkan nilai LC50 dalam g/ml (Clarkson et al., 2004)

\begin{tabular}{cc}
\hline Kriteria & nilai LC50 \\
Toksisitas & $(\mu \mathrm{g} / \mathbf{m l})$ \\
& \\
\hline
\end{tabular}

Sangat toksik $\quad 0-100$

Toksisitas sedang $\quad 100-500$
Toksisitas rendah $500-1000$

Tidak toksik

$>1000$

\section{E. Pemeriksaan kandungan MK menggunakan High Performance Thin Layer Chromatography (HPTLC)}

Untuk mengamati ada tidaknya komponen $M$. oleifera dalam madu yang diambil, dilakukan identifikasi profil KLT dari sampel madu. Madu sebanyak $15 \mathrm{~g}$ mula-mula dilarutkan dalam air kemudian dipartisi sebanyak tiga kali menggunakan $20 \mathrm{ml}$ etil asetat. Lapisan organik kemudian dikumpulkan dan pelarut diuapkan dengan bantuan evaporasi putar. Sebanyak $15 \mathrm{~g} M$. oleifera kemudian dihaluskan menggunakan mortar dan pestel kemudian ditambahkan dengan 20 $\mathrm{ml}$ air dan disaring untuk memisahkan fase padat. Cairan yang diperoleh kemudian dipartisi 3 kali menggunakan $20 \mathrm{ml}$ etil asetat lalu lapisan organik digabungkan kemudian diuapkan. Semua sampel kemudian dipartisi dengan metode yang sama masing-masing tiga kali untuk MK dan M. oleifera. Semua sampel yang diperoleh ditotolkan pada lempeng KLT silika gel $60 \mathrm{~F}_{254}\left(\right.$ Merck $\left.^{\circledR}\right)$ ukuran $5 \times 10$ cm. KLT kemudian dikembangkan menggunakan campuran etil asetat dan nheksana dengan perbandingan 2:1. Selanjutnya, pelat dipindai menggunakan CAMAG $^{\circledR} \quad$ TLC Scanner 3 di bawah 
panjang gelombang pengamatan $254 \mathrm{~nm}$. Spot-spot yang diidentifikasi di setiap sampel dibandingkan dengan menggunakan faktor retardasi (Rf) yang diperoleh

\section{HASIL DAN PEMBAHASAN}

Dengan mempertimbangkan nilai gizi dan manfaat madu dan $M$. oleifera daun serta pentingnya keamanan produk alami untuk konsumsi manusia, penelitian ini bertujuan untuk mengevaluasi toksisitas madu yang dihasilkan oleh lebah yang diberi tambahan pakan jus $M$. oleifera dengan menggunakan larva udang $A$. salina sebagai model uji. Pertama-tama, untuk mengamati ada tidaknya komponen $M$. oleifera dalam madu yang diproduksi, maka dilakukan skrining kualitatif menggunakan HPTLC dengan membandingkan profil KLT madu dengan jus $M$. oleifera. Seperti yang ditunjukkan pada Gambar 1, komponen M. oleifera ditemukan dalam madu yang diperoleh. Hasil yang diperoleh menunjukkan bahwa senyawa pada nilai Rf $0,83 \pm 0,00,0,38 \pm 0,01,0,26 \pm 0,00$ dan 0,08 \pm 0,0o diidentifikasi pada kedua sampel tetapi dalam konsentrasi relatif berbeda yang ditunjukkan oleh AUC (Tabel 2.). Keberadaan senyawa kimia dari tumbuhan juga telah dilaporkan sebelumnya pada madu di sekitar pulau Jawa dan Sumbawa di Indonesia (Yelin \& Kuntadi, 2019). Meskipun temuan ini menunjukkan bahwa komponen $M$. oleifera telah terbukti dapat ditemukan dalam madu yang dihasilkan dalam penelitian ini, perlu dilakukan penelusuran lebih lanjut untuk menentukan atau memprediksi struktur senyawa di setiap komponen yang telah dideteksi.

Tabel 2. Perbandingan profil TLC dalam hal RF dan AUC dari bintik-bintik serupa yang ditemukan pada madu kelor dan jus M.oleifera yang diperiksa di bawah sinar UV $254 \mathrm{~nm}$ menggunakan sistem HPTLC.

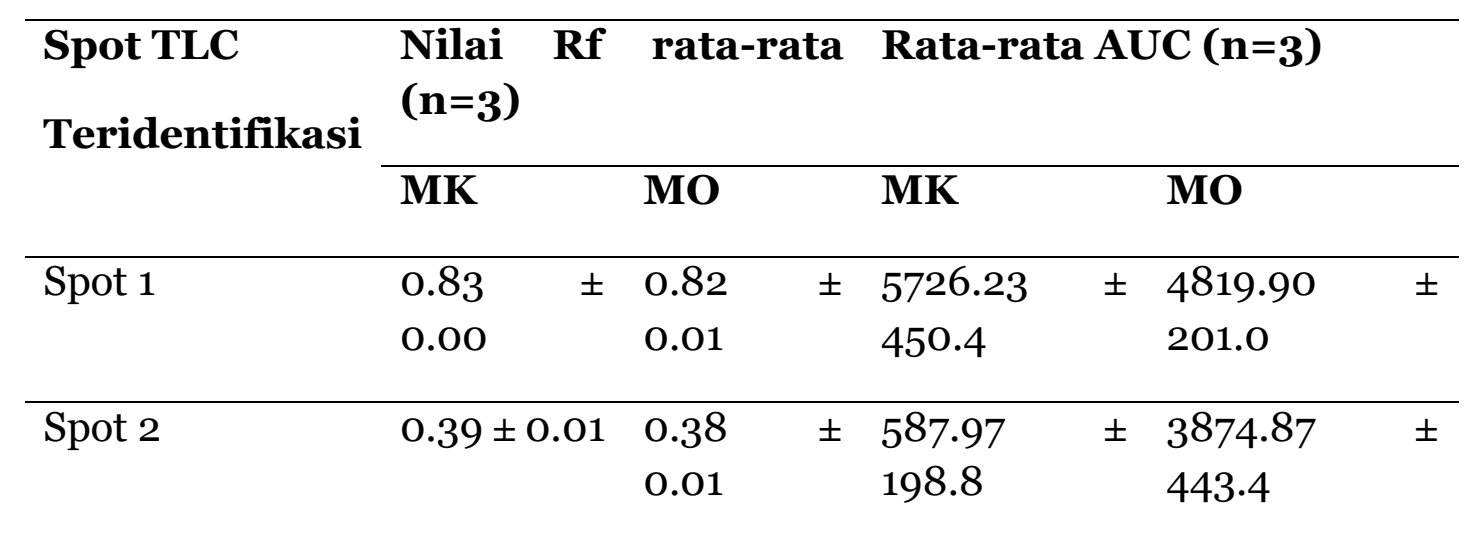




\begin{tabular}{lccccccll}
\hline Spot 3 & 0.29 & \pm & 0.26 & \pm & 2458.53 \\
& 0.01 & & 0.00 & & 117.6 & & 10935.57 \\
1253.4 & \pm \\
& & & & & & & \\
\hline Spot 4 & 0.07 & \pm & 0.08 & \pm & 449.23 & \pm & $1221.73 \pm 82.4$ \\
& 0.00 & & 0.00 & & 188.9 & & &
\end{tabular}

$\mathrm{MK}=\mathrm{Madu}$ Kelor, $\mathrm{MO}=$ M.oleifera

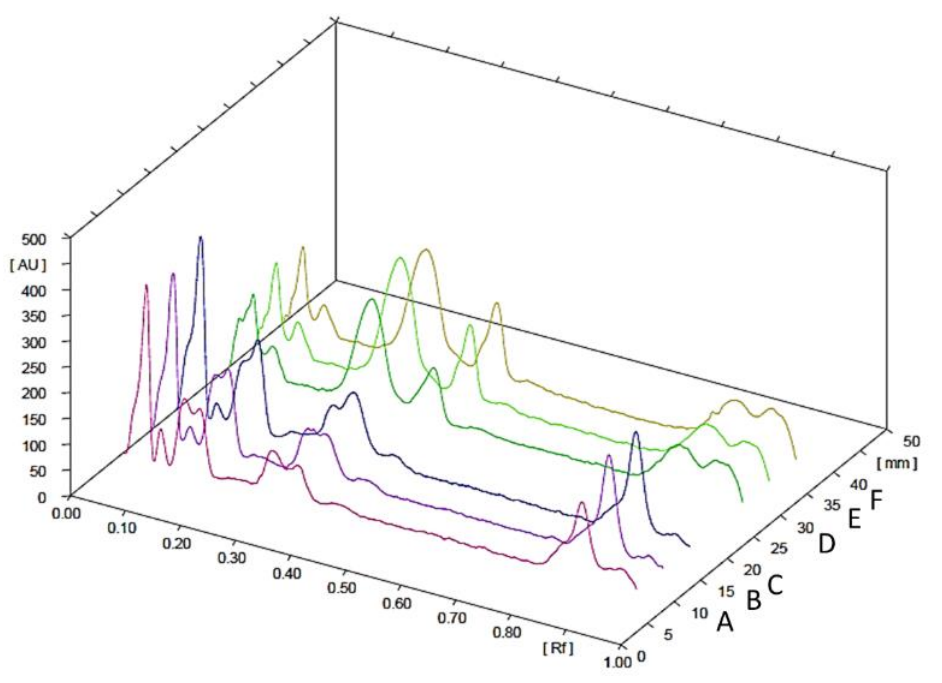

Gambar 1. Profil HPTLC dari HPTLC profiles of honey produced by feeding bees with M.oleifera juice (A-C, replicated spots) compared to the profiles of M.oleifera juice alone (D$\mathrm{F}$, replicated spots).

Tahap awal dari toksisitas pengujian menggunakan $A$. salina dilakukan dengan melakukan uji pada konsentrasi MK yang meningkat dimulai dengan konsentrasi 0,1, 1, 100, 1000 dan $5000 \mu \mathrm{g} / \mathrm{mL}$. Data yang diperoleh dari pengujian awal menunjukkan tandatanda kematian (Tabel 3) A. salina larva mulai dari konsentrasi 100 hingga 5000 $\mathrm{g} / \mathrm{mL}$. Khusus untuk konsentrasi 1000 $\mathrm{g} / \mathrm{mL}$, kematian larva udang ditemukan 100\%. Oleh karena itu, deret konsentrasi kemudian disusun kembali menggunakan deret baru mulai dari 100, 250, 500, 1000 dan $2000 \mathrm{~g} / \mathrm{mL}$ untuk mendapatkan nilai $\mathrm{LC}_{50}$ yang lebih presisi. Nilai LC $_{50}$ kemudian diperoleh dengan menggunakan persamaan regresi dengan menggunakan nilai-nilai probit dari yang sesuai persentase kematian larva. Nilai probit yang diperoleh kemudian diplot terhadap skala logaritmik untuk konsentrasi (log C) seperti yang ditunjukkan pada Gambar 2. Dari kurva kalibrasi diketahui bahwa nilai probit persentase mortalitas $A$. salina larvamenunjukkan hasil yang cukup linier $(\mathrm{r}=0,961)$. Dari persamaan ini, $\mathrm{LC}_{50}$ nilai untuk $A$. salina larva kelor madu kemudian dihitung dan nilai LC5O diperoleh pada 614,58 $\mu \mathrm{g} / \mathrm{mL}$. Berdasarkan kategori toksisitas pada 
Tabel 1, madu kelor tergolong toksisitas rendah.

Tabel 3. Hasil pengamatan setelah uji toksisitas 24 jam menggunakan larva A.salinaprobitnya terhadap MK dan analisis(n=3).

\begin{tabular}{|c|c|c|c|c|c|c|c|c|c|c|}
\hline \multirow{2}{*}{$\begin{array}{l}\text { Konsentrasi } \\
(\mu \mathrm{g} / \mathrm{mL})\end{array}$} & \multirow{2}{*}{$\begin{array}{l}\text { Log } \\
C\end{array}$} & \multicolumn{3}{|c|}{ Mortalitas } & \multirow{2}{*}{$\begin{array}{l}\text { Jumlah } \\
\text { larva }\end{array}$} & \multicolumn{3}{|c|}{$\begin{array}{c}\text { Mortality } \\
\text { (\%) }\end{array}$} & \multirow{2}{*}{$\begin{array}{l}\text { Rata-rata } \\
\% \\
\text { Mortalitas }\end{array}$} & \multirow{2}{*}{$\begin{array}{l}\text { Nilai } \\
\text { Probit }\end{array}$} \\
\hline & & $\mathbf{R 1}$ & $\mathbf{R 2}$ & $\begin{array}{l}\mathbf{R} \\
\mathbf{3}\end{array}$ & & $\mathbf{R 1}$ & R2 & R3 & & \\
\hline 100 & 2.00 & 1 & $\mathrm{O}$ & 0 & 10 & 10 & $\mathrm{O}$ & $\mathrm{O}$ & $3 \cdot 33$ & 3.12 \\
\hline 250 & 2.40 & 1 & 1 & 2 & 10 & 10 & 10 & 20 & $13 \cdot 33$ & 3.87 \\
\hline 500 & 2.70 & 2 & 3 & 3 & 10 & 20 & 30 & 30 & 26.67 & 4.39 \\
\hline 1000 & 3.00 & 5 & 7 & 7 & 10 & 50 & 70 & 70 & 63.33 & $5 \cdot 33$ \\
\hline 1500 & 3.18 & 8 & 9 & 9 & 10 & 80 & 90 & 90 & 86.67 & 6.13 \\
\hline 2000 & 3.30 & 10 & 9 & 10 & 10 & 100 & 90 & 100 & 96.67 & 6.88 \\
\hline $\begin{array}{l}\text { Negative } \\
\text { Control }\end{array}$ & - & $\mathrm{O}$ & $\mathrm{O}$ & $\mathrm{O}$ & 10 & $\mathrm{O}$ & $\mathrm{O}$ & $\mathrm{O}$ & 0.0 & 3.12 \\
\hline
\end{tabular}

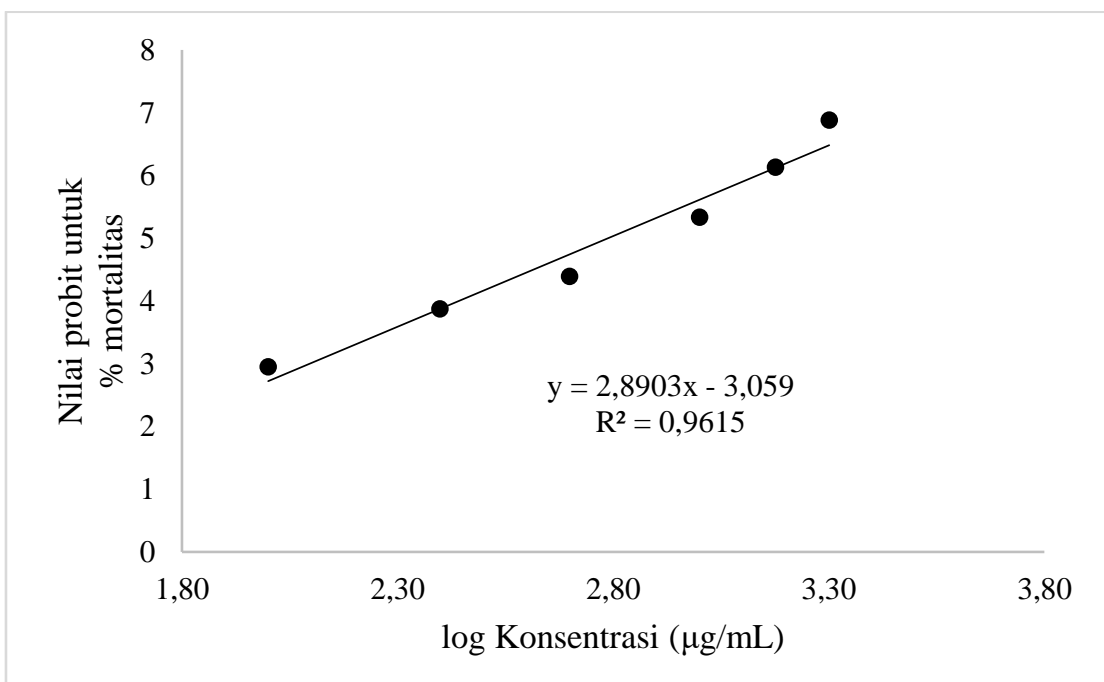

Gambar 2. Kurva kalibrasi nilai probit diperoleh dari persentase mortalitas ( $\mathrm{n}=10)$ yang diplot terhadap skala logaritmik konsentrasi Madu Kelor (MK) yang diuji.

Untuk mengamati pengaruh MK pada $A$. salina larva setelah 24 jam pengujian, larva diperiksa di bawah mikroskop. Secara umum organ-organ yang dapat diamati dapat dilihat pada Gambar 3. Pada pengamatan mikroskopis, larva A. salina yang masih hidup menunjukkan pergerakan aktif dan 
tidak ditemukan tanda-tanda kerusakan organ dibandingkan dengan larva yang mati. Selanjutnya larva yang mati menunjukkan tanda-tanda kerusakan pada thorax, antena dan abdomen yang menunjukkan perubahan warna yang lebih gelap dan tidak terlihat adanya pergerakan. Perbedaan morfologi antara larva mati dan larva hidup serta organ yang diamati secara umum dapat dilihat pada Gambar 3 .

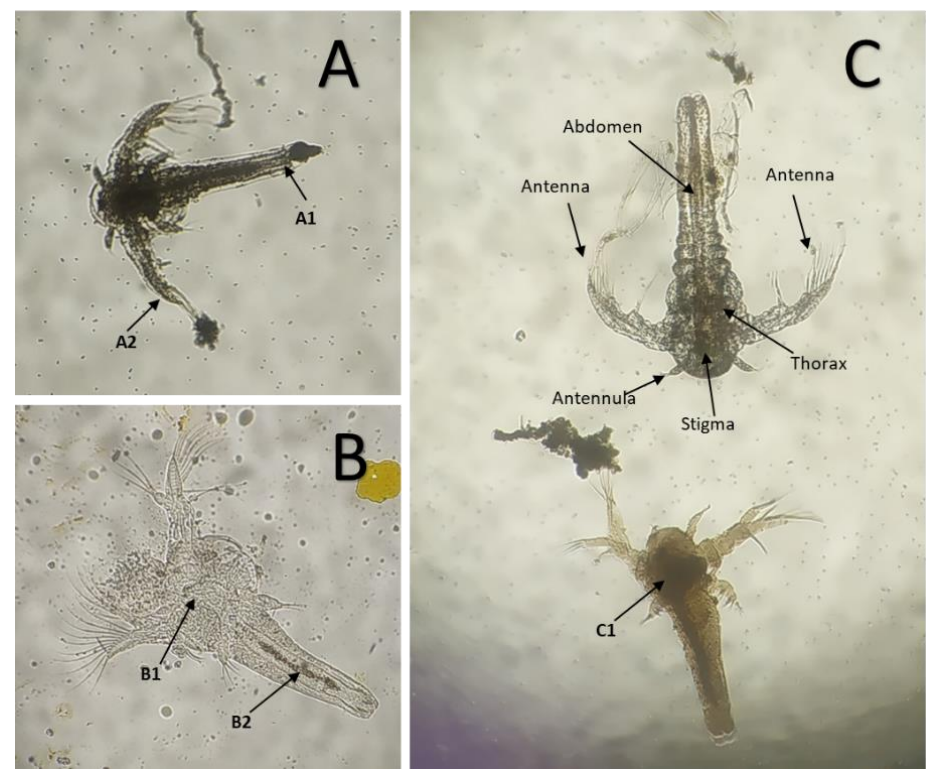

Gambar 3. Pengamatan mikroskopis larva A. salina setelah 24 jam pengujian toksisitas dalam berbagai media yang mengandung Madu Kelor (MK). Larva yang mati diamati tidak bergerak dengan warna lebih gelap di sekitar organ (A), dibandingkan dengan larva yang masih hidup (B) tidak menunjukkan cacat morfologi. Larva yang mati pada bagian A dan B juga dibandingkan dengan gambar pada bagian $\mathrm{C}$ yang menunjukkan sekumpulan organ pada A. salina: bagian perut larva yang mati (A1) dan antenanya (A2), toraks (B1) dan perut larva hidup (B2) dapat dibandingkan dengan warna gelap larva thorax mati (C1).

Secara umum, madu dianggap aman untuk dikonsumsi setiap hari. Pada umumnya, $M$. oleifera juga telah dikonsumsi di beberapa belahan dunia. Namun, penelitian juga melaporkan bahwa M. oleifera menunjukkan toksisitas pada A. salina, Biomphalaria glabra dan tikus yakni dengan nilai LD50 $>1 \mathrm{mg} / \mathrm{ml}$ (Obi, 2018), 2,37 mg/ml (Rocha-Filho et al., 2015), $1585 \mathrm{mg} / \mathrm{kg}$ (Awodele et al.,
2012), secara berturut-turut. Dalam penelitian ini, kami menemukan bahwa MK memiliki toksisitas yang rendah tetapi komponen utama yang bertanggung jawab atas toksisitas MK ini masih belum diketahui. Telah dilaporkan bahwa $M$. oleifera mengandung tanin $(8,2 \%)$, saponin (1,7\%), alkaloid (o,42\%) dan senyawa fenolik $(0,19 \%)$ sebagai metabolit sekundernya (Ojiako, 2014) tetapi 
korelasinya dengan toksisitasnya harus diselidiki lebih lanjut. Selanjutnya, dalam uji antikanker ekstrak larut air dari M.oleifera, juga dilaporkan bahwa ekstrak dapat menghambat pertumbuhan beberapa jenis sel kanker khususnya pada konsentrasi sekitar $300 \mu \mathrm{g} / \mathrm{ml}$ (Jung, 2014) yang mengindikasikan bahwa potensi sitotoksik tanaman ini juga perlu menjadi perhatian. Adedapo et.al (2009) menyarankan bahwa ekstrak air $M$. oleifera meningkatkan ALT dan AST tikus pada perkiraan dosis 400 hingga 1600 $\mathrm{mg} / \mathrm{kg}$ tetapi tidak ada tanda-tanda kematian tikus bahkan setelah pemberian akut $2000 \mathrm{mg} / \mathrm{kg}$ ekstrak air M. oleifera (Adedapo et al., 2009). Berdasarkan pengetahuan tersebut, direkomendasikan pemeriksaan lebih lanjut tentang komposisi kimia dari MK dan hubungannya dengan toksisitas yang ditemukan dalam penelitian ini.

\section{KESIMPULAN}

Dalam penelitian ini dilaporkan bahwa madu yang dihasilkan dari pemberian pakan A. mellifera dengan suplementasi M.oleifera jusmenunjukkan adanya konstituen fitokimia M.oleifera yang diidentifikasi dengan HPTLC kualitatif. Uji toksisitas yang dilakukan dalam penelitian ini menunjukkan bahwa madu yang dihasilkan dalam penelitian ini memiliki toksisitas rendah dengan $\mathrm{LC}_{50}$ berupa 614,58 $\mu \mathrm{g} / \mathrm{mL}$. Oleh karena itu, direkomendasikan penelitian lebih lanjut tentang senyawa yang mungkin ada dalam MK dan untuk menjawab apakah senyawa tersebut bertanggung jawab terhadap profil toksisitas madu ini.

\section{DAFTAR PUSTAKA}

Adedapo, A. A., Mogbojuri, O. M., \& Emikpe, B. O. (2009). Safety evaluations of the aqueous extract of the leaves of Moringa oleifera in rats. Journal of Medicinal Plants Research, 3(8), 586-591.

Awodele, O., Oreagba, I. A., Odoma, S., da Silva, J. A. T., \& Osunkalu, V. O. (2012). Toxicological evaluation of the aqueous leaf extract of Moringa oleifera Lam.(Moringaceae). Journal of Ethnopharmacology, 139(2), 330336.

Biluca, F. C., da Silva, B., Caon, T., Mohr, E. T. B., Vieira, G. N., Gonzaga, L. V., Vitali, L., Micke, G., Fett, R., \& Dalmarco, E. M. (2020). Investigation of phenolic compounds, antioxidant and anti-inflammatory activities in stingless bee honey (Meliponinae). Food Research International, 129, 108756.

Clarkson, C., Maharaj, V. J., Crouch, N. R., Grace, O. M., Pillay, P., Matsabisa, M. G., Bhagwandin, N., Smith, P. J., \& Folb, P. I. (2004). In vitro antiplasmodial activity of medicinal plants native to or naturalised in South Africa. Journal of Ethnopharmacology, 92(2-3), 177191.

Erejuwa, O. O., Sulaiman, S. A., \& Ab Wahab, M. S. (2012). Honey: a novel antioxidant. Molecules, 17(4), 44004423.

Erejuwa, O. O., Sulaiman, S. A., \& Wahab, M. S. A. (2014). Effects of honey and its mechanisms of action on the development and progression of cancer. Molecules, 19(2), 2497-2522. Estevinho, L., Pereira, A. P., Moreira, L., Dias, L. G., \& Pereira, E. (2008). Antioxidant and antimicrobial effects of phenolic compounds extracts of 
Northeast Portugal honey. Food and Chemical Toxicology, 46(12), 37743779.

Foidl, N., Makkar, H. P. S., \& Becker, K. (2001). The potential of Moringa oleifera for agricultural and industrial uses. What Development Potential for Moringa Products, 20.

Gopalakrishnan, L., Doriya, K., \& Kumar, D. S. (2016). Moringa oleifera: A review on nutritive importance and its medicinal application. Food Science and Human Wellness, 5(2), 49-56.

Hadju, V., Dassir, M., Sadapotto, A., Putranto, A., Marks, G., \& Arundhana, A. I. (2020). Effects of Moringa Oleifera Leaves and Honey Supplementation during Pregnancy on Mothers and Newborns: A Review of the Current Evidence. Open Access Macedonian Journal of Medical Sciences, 8(F), 208-214.

Israili, Z. H. (2014). Antimicrobial properties of honey. American Journal of Therapeutics, 21(4), 304323.

Jung, I. L. (2014). Soluble extract from Moringa oleifera leaves with a new anticancer activity. PloS One, 9(4), e95492.

Kwakman, P. H. S., \& Zaat, S. A. J. (2012). Antibacterial components of honey. IUBMB Life, 64(1), 48-55.

Moyo, B., Masika, P. J., Hugo, A., \& Muchenje, V. (2011). Nutritional characterization of Moringa (Moringa oleifera Lam.) leaves. African Journal of Biotechnology, 10(60), 1292512933.

Obi, O. O. O. B. C. (2018). Phytochemical, Anti-nutritional and Toxicity Assessment of Moringa Oleifera Seeds, Stem Bark and Leaves Using Brine Shrimp (Artemia Salina) Assay. Jordan Journal of Chemistry (JJC) 13(3), 171-178.

Ojiako, E. N. (2014). Phytochemical analysis and antimicrobial screening of Moringa oleifera leaves extract. International Journal of Engineering Science, 3, 32-35.

Olivieri, C., Marota, I., Rollo, F., \& Luciani, S. (2012). Tracking plant, fungal, and bacterial DNA in honey specimens. Journal of Forensic Sciences, 57(1), 222-227.

Oroian, M., \& Ropciuc, S. (2017). Honey authentication based on physicochemical parameters and phenolic compounds. Computers and Electronics in Agriculture, 138, 148156.

Parra, A. L., Yhebra, R. S., Sardiñas, I. G., \& Buela, L. I. (2001). Comparative study of the assay of Artemia salina $\mathrm{L}$. and the estimate of the medium lethal dose (LD50 value) in mice, to determine oral acute toxicity of plant extracts. Phytomedicine, 8(5), 395400.

Rajeh, M. A. B., Kwan, Y. P., Zakaria, Z., Latha, L. Y., Jothy, S. L., \& Sasidharan, S. (2012). Acute toxicity impacts of Euphorbia hirta L extract on behavior, organs body weight index and histopathology of organs of the mice and Artemia salina. Pharmacognosy Research, 4(3), 170. Rocha-Filho, C. A. A., Albuquerque, L. P., Silva, L. R. S., Silva, P. C. B., Coelho, L. C. B. B., Navarro, D. M. A. F., Albuquerque, M. C. P. A., Melo, A. M. M. A., Napoleão, T. H., \& Pontual, E. V. (2015). Assessment of toxicity of Moringa oleifera flower extract to Biomphalaria glabrata, Schistosoma mansoni and Artemia salina. Chemosphere, 132, 188-192.

Rowland, C. Y., Blackman, A. J., D'Arcy, B. R., \& Rintoul, G. B. (1995). Comparison of organic extractives found in leatherwood (Eucryphia lucida) honey and leatherwood flowers and leaves. Journal of Agricultural and Food Chemistry, 43(3), 753-763.

Shindano, J., \& Kasase, C. (2009). Moringa (Moringa oleifera): a source of food and nutrition, medicine and industrial products. ACS Publications.

Wirta, H., Abrego, N., Miller, K., Roslin, T., \& Vesterinen, E. (2021). DNA traces the origin of honey by identifying plants, bacteria and fungi. Scientific Reports, 11(1), 1-14.

Yelin, A., \& Kuntadi. (2019). 
Phytochemical identification of honey from several regions in Java and Proceedings, 2120(1), 80024.

Sumbawa. AIP Conference

Copyright (c) 2021 Jurnal Mandala Pharmacon Indonesia; This article is an open access article distributed under the terms and conditions of the Creative Commons Attribution License (http://creativecommons.org/licenses/by/4.0/) 